\title{
八丈島栄養調査報告 Nutrition Survey on Hachijo Island's Inhabitants
}

（第 3 報）血液分析からみた栄養状態

(I) Biochemical Examination of Blood

（昭和33年1 月16日受理）

柳 沢文正高野善七笠原公 (Fumimasa Yanagisawa)

(Zensichi Takano)

(Kimi Ogasawara)

桑 原 丙午生高橋 重 麿

(Himao Kuwabara) (Sigemaro Takhashi)

大 関 政 康

(Masayasu Ozeki)

赤 羽 正 之

(Masayuki Akabane)

Blood samples were collected from 76 Hachijo's inhabitants and the specific gravity and the contents of its inorganic and organic components, namlly, total serum calcium, inorganic phosphate, serum protein, albumin, and globulin were compared with those of inhabitants dwelling in nutritively improved area (area of Suginami.Nishi Health Centre, Tokyo) and it was found that total calcium and dialyzable calcium of Hachijo's inhabitants were definitely low.

第 1 報・第 2 報で，八丈島の特殊な食楅構成と栄盖掑 取状况を調査し，それにもとつく食䊓構成不均衡からく る栄羕久宿の体質に及ぼす影響を報告した。第 3 報では かかる条件のもとにある八丈島民76名の血液成分, 特に 血液比重・血清中総 $\mathrm{Ca} ・$ 透析性 $\mathrm{Ca} ・$ 総 $\mathrm{Mg} ・$ 無機 $\mathrm{P}$ 並び に血清中総蛋白・アルブミン・グロブリンを測定したの で報告する。

\section{分析方 法}

現地で央験を行ならために必要な器具器械および試蔡 類すへでを整犕して渡島し, 破検者の採血を行い, 值ち に血液比重を測定した後，血清を分離して現地において 速やかに各種の分析を行つた。

分析方法は, 血液比重は硫垔銅法, 1.) 血清総Ca ・透析 性 $\mathrm{Ca}$ お よび総 $\mathrm{Mg}$ は柳沢法, 231) 血清無機 $\mathrm{P}$ はF Fiske \& Subba Row 法5)a) 血清総蛋白およびアルブミン・ ダロブリンは Biuret 法7)を用い，いずれも Leitz 光 電此色計にて分析を行つた。

\section{実 験 結 果}

八丈島民の被検者76名の実験結果は第 1 表に示寸如く
である。佮昭和 31 年 5 月（第 1 回）と 12 月（第 2 回）に 東京都杉並西保健所管内の栄鉒調査を行つた際実施した 成績を第 2 表・第 3 表に示す。これらの平均值について は第 4 表に示すが，八丈島と杉並の第 1 回㧍よび第 2 回 の分析結果を比較してみると，血液比重は両者江差異が 認められないが，血清総 $\mathrm{Ca} \cdot$ 透析性 $\mathrm{Ca}$ 共に八丈島が低 值であり，杉亚に比し総 $\mathrm{Ca}$ は約 $0.5 \mathrm{mg} \mathrm{dl}$ 低く, 透析性 $\mathrm{Ca}$ は約 $1.0 \mathrm{mg}$ ， $\mathrm{dl}$ 低い值を示した。総 $\mathrm{Mg}$ は八丈島がや や低く，無機 $\mathrm{P}$ は両者に差がないよ5である。総蛋白に ついては, 八丈島が低值を示し，アルブミンも低く，グ ロブリンは高值であつた。従つて $\mathrm{A} / \mathrm{G}$ は八文島が低值と なる。杉並にお汗る第 1 回と第 2 回の比較では, 第 1 回 の結果が透析性Caおよび総Mgにおいて，やや低值を示 し，無機Pがわずかに高い值を示したか，その他では差 がないようである。

$$
\text { 考察 }
$$

以上の実跧結果から考察すると，第 1 報・第 2 報で報 告した如く，Caは牛乳或は野菜の不足から，基準量の $1 / 5$ 量とい5低い掑取量であることからも血清中総 $\mathrm{Ca} ・$ 透析 
第 1 表八丈岛民の血液成分分析絈果

\begin{tabular}{|c|c|c|c|c|c|c|c|c|c|c|c|c|c|}
\hline \multirow[b]{2}{*}{$\begin{array}{l}\text { 番 } \\
\text { 号 }\end{array}$} & \multirow[b]{2}{*}{\begin{tabular}{l|l} 
氏 \\
\\
\end{tabular}} & \multirow[b]{2}{*}{$\begin{array}{l}\text { 年 } \\
\text { 跲 }\end{array}$} & \multirow[b]{2}{*}{$\begin{array}{l}\text { 性 } \\
\text { 別 }\end{array}$} & \multirow{2}{*}{\multicolumn{2}{|c|}{$\begin{array}{l}\text { 值 } \\
\text { 比重 }\end{array}$}} & \multicolumn{5}{|c|}{ 血 } & \multicolumn{3}{|l|}{ 清 } \\
\hline & & & & & & $\begin{array}{l}\text { 総 } \mathrm{Ca} \\
\mathrm{mg} / \mathrm{dl}\end{array}$ & $\begin{array}{c}\text { 遂析性 } \\
\mathrm{Ca} \\
\mathrm{mg} / \mathrm{dl}\end{array}$ & $\begin{array}{l}\text { 総 } \mathrm{Mg} \\
\mathrm{mg} / \mathrm{dl}\end{array}$ & $\begin{array}{l}\text { 無機 P } \\
\mathrm{mg} / \mathrm{dl}\end{array}$ & $\begin{array}{l}\text { 䋟蛋白 } \\
\text { g/dl }\end{array}$ & 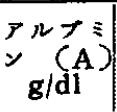 & 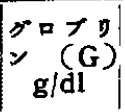 & $A / G$ \\
\hline 1 & S. S. & 42 & q & & 1,053 & 9.6 & 3.4 & 1.0 & 3.6 & 8.2 & 4.40 & 3.80 & 1.15 \\
\hline 2 & H. S. & 13 & $\varphi$ & & 1,054 & 9.6 & 3.2 & 1.5 & 4.1 & 8.0 & 4.64 & 3.36 & 1.38 \\
\hline 3 & M. A. & 40 & P & & 1,055 & 8.4 & 2.6 & 1.1 & 4.0 & 8.0 & 3.36 & 4.64 & 0.72 \\
\hline 4 & M. K. & 33 & $\delta$ & & 1,051 & 8.8 & 2.5 & 1.3 & 3.2 & 7.7 & 4.32 & 3.38 & 1.27 \\
\hline 5 & M. M. & 50 & \% & & 1,054 & 9.0 & 2.3 & 0.8 & 3.3 & 7.7 & 4.80 & 2.90 & 1.62 \\
\hline 6 & T. M. & 42 & 9 & & 1,051 & 8.4 & 2.6 & 1.4 & 4.1 & 7.6 & 4.32 & 3.28 & 1.31 \\
\hline 7 & N. M. & 17 & $\hat{o}$ & & 1,052 & 9.0 & 2.6 & 0.7 & 3.6 & 7.8 & 4.88 & 2.92 & 1.67 \\
\hline 8 & T. Y & 26 & $\uparrow$ & & 1,057 & 9.0 & 3.0 & 1.0 & 3.8 & 8.2 & 5.44 & 2.76 & 1.97 \\
\hline 9 & H. A. & 13 & 9 & & 1,051 & 8.3 & 2.2 & 1.8 & 4.6 & 7.2 & 4.32 & 2.88 & 1.50 \\
\hline 10 & T. K. & 38 & ㅇ & & 1,054 & 8.8 & 2.8 & 1.6 & 2.9 & 7.6 & 3.80 & 2.80 & 1.71 \\
\hline 11 & H. S. & 37 & q & & 1,049 & 8.8 & 2.4 & 1.5 & 3.2 & 6.8 & 4.56 & 2.24 & 2.03 \\
\hline 12 & T. S. & 59 & $\delta$ & & 1,055 & 8.6 & 2.4 & 0.8 & 3.0 & 6.7 & 4.08 & 2.62 & 1.55 \\
\hline 13 & G. M. & 11 & 3 & & 1,051 & 9.8 & 3.6 & 0.6 & 4.1 & 7.4 & 4.32 & 3.08 & 1.40 \\
\hline 14 & Y. M. & 14 & $\delta$ & & 1,056 & 8.9 & 2.1 & 1.3 & 4.1 & 6.8 & 4.32 & 2.48 & 1.74 \\
\hline 15 & F. A & 37 & \& & & 1,053 & 8.3 & 21 & 1.5 & 3.6 & 7.0 & 3.92 & 3.08 & 1.27 \\
\hline 16 & K. K. & 13 & $\delta$ & & 1,053 & 9.2 & 3.0 & 0.9 & 4.4 & 7.1 & 4.00 & 3.10 & 1.29 \\
\hline 17 & K. Y. & 16 & 9 & & 1,054 & 8.8 & 2.7 & 1.0 & 4.0 & 7.4 & 4.64 & 2.76 & 1.68 \\
\hline 18 & T. $Y$ & 58 & 甲 & & 1,048 & 8.6 & 2.6 & 1.1 & 4.1 & 7.9 & 4.48 & 3.42 & 1.30 \\
\hline 19 & K. Y. & 31 & 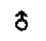 & & 1,057 & 8.8 & 29 & 1.5 & 3.0 & 7.1 & 4.64 & 2.46 & 1.88 \\
\hline 20 & K. K. & 12 & 8 & & 1,054 & 10.0 & 2.9 & 1.1 & 4.5 & 6.8 & 4.08 & 2.72 & 1.50 \\
\hline 21 & F. A. & 33 & P & & 1,051 & 9.3 & 3.2 & 1.1 & 5.1 & 6.8 & 4.32 & 2.48 & 1.74 \\
\hline 22 & K. S. & 36 & $\hat{\jmath}$ & & 1,055 & 8.0 & 2.0 & 1.6 & 3.9 & 6.8 & 3.92 & 2.88 & 1.36 \\
\hline 23 & $\mathrm{~T} \cdot \mathrm{K}$. & 35 & $q$ & & 1,052 & 9.6 & 3.4 & 1.1 & 3.5 & 7.4 & 4.32 & 3.08 & 1.40 \\
\hline 24 & T. Y. & 22 & $q$ & & 1,055 & 8.9 & 3.0 & 1.5 & 3.4 & 6.6 & 4.48 & 2.12 & 2.11 \\
\hline 25 & M. A. & 18 & 8 & & 1,055 & 10.2 & 4.5 & 0.9 & 3.0 & 7.1 & 5.28 & 1.82 & 2.90 \\
\hline 26 & T. A. & 14 & $\hat{\delta}$ & & 1,056 & 9.5 & 2.3 & 1.4 & 3.6 & 6.8 & 4.16 & 2.64 & 1.57 \\
\hline 27 & A. S. & 17 & $\hat{o}$ & & 1,056 & 9.9 & 2.6 & 1.0 & 3.6 & 7.1 & 4.88 & 2.22 & 2.19 \\
\hline 28 & M. K. & 12 & 우 & & 1,052 & 9.3 & 2.9 & 0.7 & 4.5 & 6.5 & 4.64 & 1.86 & 2.49 \\
\hline 29 & T. K. & 40 & 7 & & 1,053 & 9.3 & 2.4 & 1.4 & 4.0 & 7.2 & 4.40 & 2.80 & 1.57 \\
\hline 30 & T. Y. & 50 & $\delta$ & & 1,053 & 9.5 & 2.4 & 0.9 & 3.4 & 7.2 & 4.08 & 3.12 & 1.30 \\
\hline 31 & G. Y. & 46 & 9 & & 1,052 & 10.2 & 3.5 & 0.8 & 3.6 & 6.8 & 4.08 & 2.72 & 1.50 \\
\hline 32 & A. Y. & 14 & 우 & & 1,053 & 8.9 & 2.0 & 1.6 & 4.3 & 6.8 & 4.08 & 2.72 & 1.50 \\
\hline 33 & H. S. & 52 & 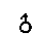 & & 1,059 & 9.5 & 2.8 & 1.2 & 3.6 & 6.9 & 4.72 & 2.18 & 2.16 \\
\hline 34 & A. S. & 49 & q & & 1,054 & 9.9 & 3.6 & 1.4 & 4.1 & 7.2 & 4.32 & 2.88 & 1.50 \\
\hline 35 & T. M. & 42 & $\delta$ & & 1,061 & 9.2 & 2.8 & 1.5 & 3.4 & 6.8 & 4.32 & 2.48 & 1.74 \\
\hline 36 & T. S. & 15 & $\delta$ & & 1,055 & 9.5 & 3.0 & 1.3 & 5.4 & 7.3 & 5.44 & 1.86 & 2.92 \\
\hline 37 & G. T. & 28 & $\delta$ & & 1,060 & 9.5 & 2.5 & 0.7 & 3.8 & 7.0 & - & - & - \\
\hline 38 & G. $\mathbf{O}$ & 18 & $\delta$ & & 1,056 & 10.0 & 3.0 & 0.6 & 3.6 & 7.2 & 4.64 & 2.56 & 1.81 \\
\hline 39 & T. O. & 15 & $\delta$ & & 1,055 & 10.0 & 3.0 & 0.6 & 4.6 & 7.2 & 4.32 & 2.88 & 1.50 \\
\hline 40 & H. O.! & 59 & $\delta$ & & 1,055 & 9.5 & 2.9 & 0.95 & 3.4 & 7.2 & 3.68 & 3.52 & 1.04 \\
\hline
\end{tabular}


第11巻 第 2 号

\begin{tabular}{|c|c|c|c|c|c|c|c|c|c|c|c|c|}
\hline 41 & H. A. & 12 & $q$ & 1,055 & 9.8 & 2.5 & 0.9 & 3.8 & 7.2 & 3.76 & 3.44 & 1.09 \\
\hline 42 & S. F. & 38 & $\widehat{\delta}$ & 1,054 & 9.2 & 2.6 & 1.1 & 3.9 & 6.8 & 4.08 & 2.72 & 1.50 \\
\hline 43 & S. T. & 76 & ㅇ & 1,052 & 9.4 & 26. & 0.9 & 3.6 & 6.6 & 3.52 & 3.08 & 1.14 \\
\hline 44 & K. U. & 62 & ㅇ & 1,054 & 9.3 & 2.0 & 1.6 & 3.1 & 7.7 & 4.00 & 3.70 & 1.09 \\
\hline 45 & N. U. & 67 & $\hat{\partial}$ & 1,055 & 10.0 & 4.6 & 0.4 & 3.6 & 7.3 & 4.48 & 2.82 & 1.58 \\
\hline 46 & S. A. & 52 & q & 1,055 & 9.2 & 2.2 & 1.7 & 2.1 & 7.4 & 3.84 & 3.56 & 1.07 \\
\hline 47 & S. S. & 35 & $\hat{o}$ & 1,052 & 9.9 & 3.9 & 0.7 & 3.4 & 6.7 & 3.86 & 2.84 & 1.35 \\
\hline 48 & H. A. & 32 & $\rho$ & 1,050 & 9.4 & 2.2 & 1.1 & 3.8 & 7.0 & 4.32 & 2.68 & 1.61 \\
\hline 49 & T. 0 & 44 & $q$ & 1,049 & 10.0 & 3.4 & 0.5 & 4.1 & 7.8 & 4.48 & 3.32 & 1.34 \\
\hline 50 & $\mathrm{~K} \cdot \mathrm{M}$. & 44 & $q$ & 1,055 & 8.8 & 2.3 & 1.9 & 3.5 & 7.4 & 4.08 & 3.32 & 1.22 \\
\hline 51 & $\mathrm{~T} . \mathrm{M}$ & 22 & q & 1,056 & 8.8 & 2.6 & 1.9 & 4.1 & 7.7 & 3.52 & 4.18 & 0.84 \\
\hline 52 & Y. M. & 15 & $\hat{o}$ & 1,056 & 9.8 & 3.1 & 0.7 & 3.2 & 7.4 & 4.08 & 3.32 & 1.22 \\
\hline 53 & A. K. & 47 & 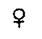 & 1,054 & 9.0 & 3.3 & 1.6 & 3.2 & 7.4 & 3.60 & 3.80 & 0.94 \\
\hline 54 & S. A. & 28 & $q$ & 1,053 & 8.6 & 2.3 & 1.1 & 3.2 & 7.4 & 4.32 & 3.08 & 1.40 \\
\hline 55 & N. A. & 44 & o & 1,053 & 9.4 & 3.1 & 0.7 & 3.3 & 7.4 & 3.44 & 3.96 & 0.86 \\
\hline 56 & $\mathrm{~T} . \mathrm{Y}$ & 19 & q & 1,052 & 9.9 & 3.6 & 0.5 & 3.7 & 7.0 & 3.68 & 3.32 & 1.10 \\
\hline 57 & $\mathrm{~K} \cdot \mathrm{T}$. & 24 & $\hat{o}$ & 1,058 & 9.6 & 3.1 & 1.2 & 2.7 & 7.4 & 4.08 & 3.32 & 1.22 \\
\hline 58 & M. S. & 42 & q & 1,053 & 10.0 & 4.1 & 0.4 & 2.8 & 6.6 & 3.76 & 2.84 & 1.32 \\
\hline 59 & M. A. & 42 & $q$ & 1,053 & 9.8 & 3.3 & 0.8 & 2.9 & 6.7 & 3.20 & 3.50 & 0.91 \\
\hline 60 & T. S. & 53 & ㅇ & 1,054 & 9.8 & 2.4 & 1.3 & 4.6 & 7.3 & 4.16 & 3.14 & 1.38 \\
\hline 61 & T. 0 & 19 & 우 & 1,051 & 9.3 & 2.5 & 0.9 & 4.0 & 6.8 & 3.86 & 2.94 & 1.31 \\
\hline 62 & F. K. & 32 & 우 & 1,051 & 9.4 & 2.3 & 0.9 & 3.2 & 7.3 & 3.92 & 3.38 & 1.16 \\
\hline 63 & S. M. & 37 & o & 1,054 & 8.7 & 2.5 & 0.9 & 3.0 & 7.4 & 4.32 & 3.08 & 1.40 \\
\hline 64 & S. A. & 56 & $q$ & 1,053 & 9.3 & 3.1 & 0.8 & 3.2 & 7.4 & 4.96 & 2.44 & 2.03 \\
\hline 65 & A. S. & 34 & 9 & 1,052 & 9.3 & 3.5 & 0.9 & 3.1 & 7.3 & 4.00 & 3.30 & 1.21 \\
\hline 66 & A. S. & 30 & $\delta$ & 1,053 & 9.4 & 3.9 & 1.4 & 3.0 & 7.8 & 4.16 & 3.64 & 1.14 \\
\hline 67 & N. S. & 25 & $q$ & 1,053 & 8.5 & 2.4 & 1.1 & 3.5 & 7.3 & 3.84 & 3.46 & 1.11 \\
\hline 68 & T. Y. & 38 & q & 1,054 & 9.4 & 3.3 & 0.7 & 3.2 & 7.2 & 3.60 & 3.60 & 1.00 \\
\hline 69 & S. M. & 33 & $\hat{o}$ & 1,053 & 9.3 & 3.2 & 0.7 & 3.5 & 7.0 & 3.12 & 3.88 & 0.84 \\
\hline 70 & T. H. & 26 & 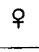 & 1,050 & 10.4 & 3.9 & 0.4 & 4.0 & 6.7 & 3.84 & 2.86 & 1.35 \\
\hline 71 & Н. Н. & 32 & $\hat{o}$ & 1,054 & 9.0 & 3.8 & 0.6 & 3.8 & 6.6 & 4.16 & 2.44 & 1.74 \\
\hline 72 & s. 0. & 37 & + & 1,053 & 9.0 & 2.6 & 0.8 & 3.3 & 7.0 & 3.36 & 3.64 & 1.08 \\
\hline 73 & H. Y. & 37 & $\mathcal{Z}$ & 1,054 & 9.8 & 3.6 & 0.3 & 3.4 & 6.8 & 4.16 & 2.64 & 1.57 \\
\hline 74 & F. A. & 42 & $\hat{o}$ & 1,052 & 9.3 & 2.9 & 0.7 & 2.7 & 6.6 & 4.16 & 2.44 & 1.70 \\
\hline 75 & S. M. & 50 & \& & 1,053 & 10.0 & 3.2 & 0.7 & 3.0 & 6.6 & 3.84 & 2.76 & 1.39 \\
\hline 76 & T. A. & 41 & $q$ & 1,053 & 9.8 & 4.0 & 0.7 & 3.5 & 7.2 & 3.12 & 4.08 & 1.30 \\
\hline
\end{tabular}


第 2 表杉並地区住民の血政成分分析結果

\begin{tabular}{|c|c|c|c|c|c|c|c|c|c|c|c|c|}
\hline \multirow{2}{*}{$\begin{array}{l}\text { 番 } \\
\text { 号 }\end{array}$} & \multirow{2}{*}{$\begin{array}{l}\text { 氏 } \\
\text { 名 }\end{array}$} & \multirow{2}{*}{$\begin{array}{l}\text { 年 } \\
\text { 战命 }\end{array}$} & \multirow{2}{*}{$\begin{array}{l}\text { 性 } \\
\text { 別 }\end{array}$} & 血 & & \multicolumn{3}{|c|}{ ，血 } & \multicolumn{2}{|r|}{ 清 } & \multirow[b]{2}{*}{ 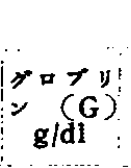 } & \multirow[b]{2}{*}{$\mathbf{A} / \mathbf{G}$} \\
\hline & & & & 重 & $\begin{array}{c}\text { 秘 } \mathrm{Ca} \\
\mathrm{mg} / \mathrm{dl}\end{array}$ & $\begin{array}{c}\text { 谁析性 } \\
\mathrm{Ca} \\
\mathrm{mg} / \mathrm{dl}\end{array}$ & $\begin{array}{l}\text { 維 } \mathrm{Mg} \\
\mathrm{mg} / \mathrm{dl}\end{array}$ & $\begin{array}{l}\text { 無祀P } \\
\mathrm{mg} / \mathrm{dl}\end{array}$ & $\begin{array}{c}\text { 総蛋白 } \\
\text { g/dl }\end{array}$ & 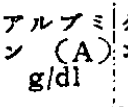 & & \\
\hline 1 & K. M. & 25 & 우 & 1,054 & 9.6 & 4.1 & 1.5 & 2.5 & 7.4 & 4.40 & 3.00 & 1.47 \\
\hline 2 & G. M. & 32 & $q$ & 1,052 & 9.8 & 3.4 & 1.4 & 3.4 & 7.6 & 4.10 & 3.50 & 1.17 \\
\hline 3 & K. $\mathbf{T}$ & 23 & $z$ & 1,059 & 10.4 & 4.4 & 0.6 & 3.3 & 7.5 & 4.00 & 3.50 & 1.14 \\
\hline 4 & S. K. & 33 & $\delta$ & 1,053 & 9.8 & 3.4 & 1.3 & 3.6 & 7.3 & 4.10 & 3.20 & 1.28 \\
\hline 5 & T. 0 & 55 & 우 & 1,054 & 9.6 & 4.1 & 1,1 & 3.8 & 6.7 & 4.20 & 3.50 & 1.68 \\
\hline 6 & F. M. & 37 & ㅇ & 1,054 & 9.0 & 3.3 & 2.1 & 3.2 & 7.4 & 4.70 & 2.70 & 1.74 \\
\hline 7 & A. $\mathrm{T}$. & 23 & ㅇ & 1,052 & 9.8 & 3.0 & 1.1 & 3.6 & 7.8 & 4.70 & 3.10 & 1.51 \\
\hline 8 & K. N. & 51 & 우 & 1,052 & 9.0 & 3.0 & 1.0 & 3.9 & 5.9 & 3.70 & 2.20 & 1.68 \\
\hline 9 & T. 0 & 55 & 8 & 1,052 & 9.6 & 3.0 & 1.5 & 2.5 & 6.7 & 3.00 & 3.70 & 0.81 \\
\hline 10 & S. 5. & 31 & 9 & 1,051 & 10.2 & 3.8 & 0.6 & 3.4 & 7.1 & 3.80 & 3.30 & 1.15 \\
\hline 11 & K. Y. & 37 & q & 1,053 & 9.0 & 3.8 & 1.2 & 3.7 & 7.3 & 4.70 & 2.70 & 1.74 \\
\hline 12 & S. N. & 36 & 9 & 1,048 & 10.0 & 3.6 & 0.6 & 3.7 & 7.5 & 5.00 & 2.50 & 2.00 \\
\hline 13 & O. K. & 51 & ㅇ & $1,050^{\prime}$ & 9.8 & 3.4 & 0.9 & 3.9 & 7.3 & 4.40 & 2.90 & 1.51 \\
\hline 14 & N. T. & 51 & 9 & 1,055 & 9.8 & 3.4 & 1.2 & 4.1 & 6.9 & 4.10 & 2.80 & 1.47 \\
\hline 15 & N. N. & 68 & 9 & 1,051 & 9.8 & 3.4 & 1.0 & 3.3 & 7.0 & 4.10 & 2.90 & 1.41 \\
\hline 16 & H. A. & 44 & 우 & 1,050 & 11.0 & 4.6 & 0.2 & 3.3 & 7.3 & 4.20 & 3.10 & 1.35 \\
\hline 17 & K. N. & 56 & $q$ & 1,053 & 10.2 & 3.6 & 1.7 & 3.9 & 7.3 & 4.30 & 3.00 & 1.43 \\
\hline 18 & Y. K. & 28 & q & 1,054 & 9.8 & 3.4 & 1.0 & 4.3 & 7.6 & 4.60 & 3.00 & 1.53 \\
\hline 19 & Y. M. & 25 & 9 & 1,053 & 9.8 & 4.3 & 0.8 & 3.8 & 7.8 & 4.40 & 3.40 & 1.29 \\
\hline 20 & I. M. & 20 & 우 & 1,054 & 9.4 & 3.4 & 1.4 & 3.9 & 7.5 & 4.00 & 3.50 & 1.14 \\
\hline 21 & S. Y. & 43 & 우 & 1,055 & 9.8 & 3.6 & 1.2 & 4.0 & 9.0 & 5.00 & 4.00 & 1.25 \\
\hline 22 & F. K. & 41 & 우 & 1,051 & 9.8 & 4.0 & 1.4 & 4.1 & 6.9 & 4.56 & 2.34 & 1.94 \\
\hline 23 & M. T. & 54 & 우 & 1,051 & 9.8 & 4.0 & 1.6 & 4.0 & 7.3 & 4.80 & 2.50 & 1.92 \\
\hline 24 & K. S & 57 & 우 & 1,050 & 9.8 & 3.8 & 1.3 & 3.6 & $7.0 !$ & 4.72 & 2.28 & 2.07 \\
\hline 25 & T. S. & 27 & $\jmath$ & 1,051 & 9.5 & 3.7 & 1.3 & 2.9 & 6.7 & 4.72 & 1.98 & 2.38 \\
\hline 26 & T. Y. & 56 & 9 & 1,052 & 10.5 & 5.0 & 0.8 & 3.1 & 7.4 & 4.72 & 2.72 & 1.70 \\
\hline 27 & T. T. & 23 & ? & 1,051 & 9.5 & 3.9 & 1.6 & 3.6 & 7.4 & 4.72 & 2.68 & 1.70 \\
\hline 28 & S. A & 55 & 9 & 1,052 & 9.8 & 3.6 & 2.1 & 2.9 & 6.9 & 4.16 & 2.74 & 1.51 \\
\hline 29 & K. H. & 60 & $\hat{o}$ & 1,052 & 10.4 & 4.8 & 1.1 & 3.8 & 7.5 & 4.72 & 2.78 & 1.69 \\
\hline 30 & A. Y. & 22 & P & 1,053 & 10.4 & 4.4 & 1.4 & 3.7 & 7.7 & 5.52 & 2.18 & 2.07 \\
\hline 31 & A. $T$. & 15 & $\delta$ & 1,051 & 9.6 & 4.5 & 1.8 & 5.0 & 7.3 & 4.92 & 2.58 & 1.83 \\
\hline 32 & F. M. & 53 & † & 1,050 & 9.0 & 3.2 & 2.3 & 3.4 & 7.6 & 4.96 & 2.68 & 1.88 \\
\hline 33 & $\mathrm{~T} . \mathrm{Y}$ & 18 & 우 & 1,050 & 9.4 & 4.0 & 1.8 & 4.7 & 7.2 & 4.96 & 2.24 & 2.21 \\
\hline 34 & K. Y & 15 & 9 & 1,053 & 10.2 & 3.7 & 1.3 & 4.7 & 6.5 & 5.12 & 1.38 & 3.71 \\
\hline 35 & H. A. & 38 & $q$ & 1,048 & 10.0 & 4.9 & 1.3 & 3.6 & 8.2 & 5.36 & 2.84 & 1.81 \\
\hline 36 & H. N. & 37 & $q$ & 1,048 & 10.2 & 4.4 & 1.1 & 2.7 & 7.6 & $4.96 !$ & 2.68 & 1.87 \\
\hline 37 & K. H. & 34 & $s$ & 1,052 & 10.0 & 4.9 & 1.7 & 3.6 & 7.2 & 4.80 & 2.40 & 2.00 \\
\hline 38 & K. O & 29 & $\hat{\alpha}$ & 1,059 & 10.7 & 4.5 & 0.6 & 4.3 & 7.7 & 5.92 & 1.78 & 3.32 \\
\hline 39 & M. S. & 39 & $\hat{o}$ & 1,056 & 10.7 & 4.7 & 1.0 & 3.9 & 7.3 & 5.20 & 2.10 & 2.95 \\
\hline 40 & K. A. & 23 & $\delta$ & 1,053 & $9.6:$ & 3.4 & 1.6 & 3.7 & 7.6 & 4.40 & 3.20 & 1.37 \\
\hline
\end{tabular}




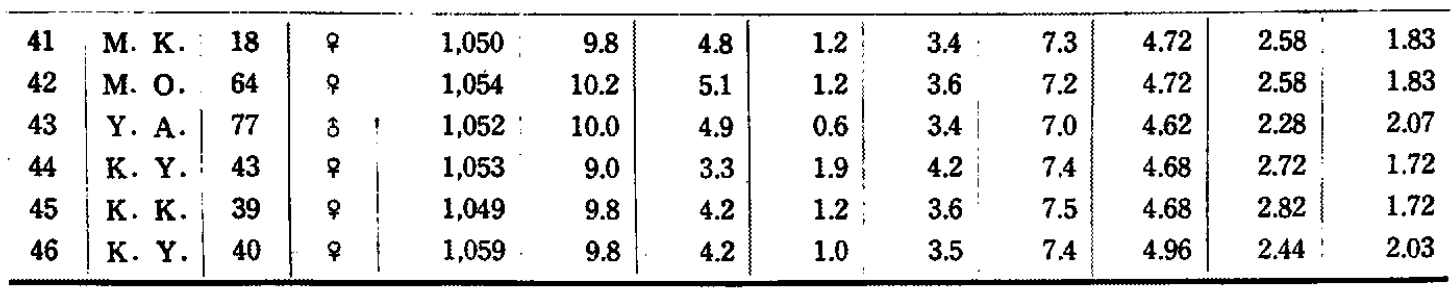

第 3 表杉並地区住民口血液成分分析結果

\begin{tabular}{|c|c|c|c|c|c|c|c|c|c|c|c|c|}
\hline \multirow{2}{*}{$\begin{array}{l}\text { 番 } \\
\text { 号 }\end{array}$} & \multirow{2}{*}{$\begin{array}{l}\text { 氏 } \\
\text { 名 }\end{array}$} & \multirow{2}{*}{$\begin{array}{l}\text { 年 } \\
\text { 龄 }\end{array}$} & \multirow{2}{*}{$\begin{array}{l}\text { 性 } \\
\text { 別 }\end{array}$} & \multirow{2}{*}{$\begin{array}{l}\text { 液 } \\
\text { 重 }\end{array}$} & \multicolumn{5}{|c|}{ 血 } & \multicolumn{3}{|l|}{ 清 } \\
\hline & & & & & $\begin{array}{l}\text { 総 } \mathrm{Ca} \\
\mathrm{mg} / \mathrm{dl}\end{array}$ & $\begin{array}{c}\text { 透析性 } \\
\mathrm{mg} / \mathrm{dl}\end{array}$ & $\begin{array}{l}\text { 棇 } \mathrm{Mg} \\
\mathrm{mg} / \mathrm{dl}\end{array}$ & $\begin{array}{l}\text { 無機 P } \\
\mathrm{mg} / \mathrm{dl}\end{array}$ & $\begin{array}{l}\text { 総蛋白 } \\
\mathrm{g} / \mathrm{dl}\end{array}$ & \begin{tabular}{lll}
$>$ & \multicolumn{1}{c}{} \\
2 & $(\mathrm{~A})$ \\
$\mathrm{g} / \mathrm{dl}$
\end{tabular} & 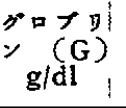 & $A / G$ \\
\hline 1 & A. 0. & 63 & $\delta$ & 1,050 & 9.2 & 3.2 & 1.6 & 2.1 & 6.9 & 4.32 & 2.58 & 1.68 \\
\hline 2 & T. Y. & 18 & q & 1,050 . & 10.3 & 4.1 & 0.2 & 3.9 & 7.4 & 4.24 & 3.16 & 1.34 \\
\hline 3 & M. T. & 53 & q & 1,052 & 10.0 & 3.0 & 1.6 & 4.0 & 7.0 & 4.48 & 2.52 & 1.77 \\
\hline 4 & Y. M. & 24 & 9 & 1,052 & 9.7 & 4.6 & 1.8 & 3.9 & 7.7 & 4.72 & 2.98 & 1.58 \\
\hline 5 & $\mathbf{Y} . \mathbf{K}$ & 28 & $q$ & 1,053 & 10.3 & 4.3 & 1.9 & 2.5 & 7.1 & 4.80 & 2.30 & 2.08 \\
\hline 6 & A. I. & 64 & 9 & 1,053 & 10.2 & 3.7 & $1.3 !$ & 3.7 & 6.6 & 4.32 & 2.28 & 1.89 \\
\hline 7 & K. Y. & 14 & 웅 & 1,050 & 9.4 & 3.3 & 1.6 & 5.3 & 7.0 & 4.48 & 2.54 & 1.77 \\
\hline 8 & K. M. & 50 & $\hat{\delta}$ & 1,051 & 10.0 & 3.2 & 0.4 & 3.5 & 6.7 & 4.32 & 3.38 & 1.27 \\
\hline 9 & M. M. & 61 & $\hat{s}$ & 1,055 & 9.4 & 3.2 & 1.7 & 3.4 & 7.5 & 4.72 & 2.78 & 1.69 \\
\hline 10 & H. O. & 56 & ㅇ & 1,050 & 10.2 & 3.2 & 1.2 & 3.2 & 6.9 & 4.48 & 2.42 & 1.85 \\
\hline 11 & F. T. & 23 & ㅇ & 1,052 & 10.2 & 4.5 & 0.2 & 3.4 & 6.4 & 4.48 & 1.92 & 2.33 \\
\hline 12 & M. T. & 38 & \& & 1,050 & 10.2 & 4.0 & 1.4 & 3.3 & 6. & 4.16 & 2.64 & 1.57 \\
\hline 13 & H. N. & 10 & 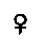 & 1,051 & 9.7 & 4.1 & 0.5 & 4.5 & 7.0 & 4.56 & 2,44 & 1.86 \\
\hline 14 & K. H. & 37 & i & 1,050 & 10.2 & 3.7 & 2.7 & 3.5 & 7.7 & $4.40^{!}$ & 3.30 & 1.33 \\
\hline 15 & A. H. & 59 & 7 & 1,051 & 10.2 & 3.1 & 1.5 & 3.8 & 6.5 & 4.56 & 1.94 & 2.35 \\
\hline 16 & H. H. & 38 & $q$ & 1,052 & 9.3 & 4. & 0.9 & 3.7 & 7. & 4.48 & 3.02 & 1.48 \\
\hline 17 & T. M. & 32 & ㅇ & 1,050 & 10.0 & 3.5 & 0.8 & 2.8 & 6.5 & 4.08 & 2.42 & 1.61 \\
\hline 18 & s. T. & 29 & $\delta$ & 1,054 & 10.0 & 3.5 & 0.7 & 3.3 & 7.2 & 4.72 & 2.48 & 1.90 \\
\hline 19 & H. T. & 44 & $\delta$ & 1,053 & 10.0 & 3.6 & 1.2 & 3.0 & 6.7 & 4.40 & 2.30 & 1.91 \\
\hline 20 & H. T. & 21 & $\hat{o}$ & 1,052 & 9.7 & 3.2 & 1.1 & 3.0 & 7.8 & 4.32 & 3.48 & 1.24 \\
\hline 21 & T. T. & 26 & 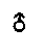 & 1,054 & 9.4 & 3. & 0.4 & 2.7 & 6.4 & 4.40 & 3.00 & 1.46 \\
\hline 22 & H. M. & 31 & 9 & 1,049 & 10.0 & 3.2 & 1.3 & 1.9 & 7.2 & 4.40 & 2.80 & 1.57 \\
\hline 23 & S. S. & 31 & $q$ & 1,051 & 9.7 & 3.0 & 1.4 & 2.2 & 7.3 & 4.24 & 3.06 & 1.38 \\
\hline 24 & F. K. & 30 & $q$ & 1,051 & 9.7 & 2.8 & 1.2 & 3.1 & 6.5 & 4.16 & 2.34 & 1.77 \\
\hline 25 & A. M. & 37 & 9 & 1.050 & 9.3 & 3.9 & 1.0 & 2.4 & 6.1 & 4.72 & 2.38 & 1.98 \\
\hline 26 & G. I & 28 & 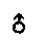 & 1,053 & 10.4 & T. & 1.2 & 2.8 & 7.3 & 4.80 & 2.50 & 1.92 \\
\hline 27 & T. S. & 39 & $\delta$ & 1,049 & 10.4 & 4.1 & 1.0 & 1.8 & 7.6 & 4.08 & 3.52 & 1.15 \\
\hline 28 & T. T. & 39 & $q$ & 1,052 & 9.3 & 3.5 & 1.1 & 3.4 & 8.1 & 5.44 & 2.66 & 2.04 \\
\hline 29 & K. T. & 12 & 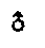 & 1,050 & 10.0 & 3.6 & 1.4 & 5.0 & 6.1 & 4.08 & 2.02 & 2.01 \\
\hline 30 & K. F. & 41 & \% & 1,051 & 9.3 & 4.2 & 2.4 & 3.0 & 7.9 & 3.72 & 3.18 : & 1.47 \\
\hline
\end{tabular}




\begin{tabular}{|c|c|c|c|c|c|c|c|c|c|c|c|c|}
\hline 31 & A. F. & 44 & q & 1,050 & 9.7 & 4.5 & 1.7 & 3.0 & 7.7 & 4.40 & 3.30 & 1.99 \\
\hline 32 & A. I . & 76 & $\hat{o}$ & 1,053 & 9.0 & 3.8 & 1.9 & 3.1 & 6.8 & 4.02 & 2.78 & 1.84 \\
\hline 33 & T. F. & 75 & $\delta$ & 1,054 & 7.4 & 2.4 & 2.2 & 2.5 & 8.8 & 4.88 & 3.92 & 1.24 \\
\hline 34 & K. M. & 62 & $\uparrow$ & 1,050 & 9.7 & 3.7 & 1.7 & 2.6 & 7.3 & 4.40 & 2.90 & 1.51 \\
\hline 35 & K. S. & 33 & $q$ & 1,052 & 9.0 & 3.5 & 1.6 & 2.4 & 7.7 & 4.48 & 3.22 & 1.39 \\
\hline 36 & I. T. & 66 & $\hat{o}$ & 1,052 & 9.4 & 3.4 & 1.6 & 2.9 & 6.8 & 4.32 & 2.48 & 1.74 \\
\hline 37 & S. K. & 55 & $\hat{\delta}$ & 1,052 & 9.8 & 3.8 & 1.6 & 3.1 & 7.3 & 4.86 & 2.44 & 1.99 \\
\hline 38 & S. N. & 33 & ○ & 1,050 & 9.7 & 4.2 & 1.2 & 2.8 & 8.0 & 4.56 & 3.44 & 1.32 \\
\hline 39 & T. T. & 44 & o & 1,051 & 9.1 & 3.6 & 2.1 & 3.4 & 7.6 & 5.36 & 2.24 & 2.38 \\
\hline 40 & S. E. & 55 & q & 1,051 & 9.0 & 3.7 & 1.8 & 3.0 & 7.1 & 4.40 & 2.70 & 1.62 \\
\hline 41 & K. T. & 51 & q & 1,050 & 9.4 & 4.4 & 2.1 & 4.0 & 7.5 & 4.56 & 2.94 & 1.55 \\
\hline 42 & G. M. & 32 & 우 & 1,051 & 9.4 & 3.7 & 1.9 & 3.5 & 7.7 & 4.72 & 2.98 & 1.57 \\
\hline 43 & N. K. & 51 & q & 1,050 & 9.7 & 3.7 & 1.6 & 3.4 & 7.6 & 4.32 & 3.28 & 1.32 \\
\hline 44 & K. N. & 25 & $q$ & 1,056 & 10.0 & 3.3 & 1.5 & 3.4 & 8.4 & 4.64 & 3.76 & 1.23 \\
\hline 45 & M. N. & 26 & P. & 1,053 & 9.4 & 3.2 & 2.0 & 3.1 & 7.8 & 6.24 & 3.56 & 1.19 \\
\hline 46 & T. D. & 55 & $q$ & 1,050 & 9.7 & 4.4 & 2.3 & 3.1 & 7.4 & 4.88 & 2.52 & 1.93 \\
\hline 47 & $\mathrm{~T} . \mathrm{K}$ & 39 & $\delta$ & 1,051 & 9.7 & 4.2 & 1.8 & 3.1 & 7.3 & 4.32 & 2.98 & 1.44 \\
\hline 48 & K. K. & 57 & † & 1,051 & 9.4 & 4.2 & 1.1 & 2.1 & 7.5 & 4.56 & 2.94 & 1.55 \\
\hline 49 & S. M. & 30 & $\hat{o}$ & 1,056 & 9.7 & 4.4 & 1.5 & 3.4 & 7.4 & 4.40 & 3.00 & 1.46 \\
\hline 50 & M. F. & 53 & q & 1,053 & 9.7 & 5.0 & 2.8 & 3.1 & 8.3 & 4.40 & 3.90 & 1.15 \\
\hline 51 & H. A. & 59 & ㅇ & 1,052 & 10.3 & 4.8 & 1.2 & 3.0 & 7.9 & 4.80 & 3.10 & 1.56 \\
\hline 52 & N. A. & 23 & $q$ & 1,049 & 10.0 & 4.5 & 0.8 & 3.8 & 7.0 & 4.70 & 2.30 & 2.04 \\
\hline 53 & N. N. & 68 & q & 1,051 & 9.8 & 4.5 & 1.5 & 2.4 & 7.7 & 4.32 & 3.38 & 1.27 \\
\hline 54 & K. H. & 19 & q & 1,053 & 9.7 & 3.5 & 1.8 & 3.4 & 7.6 & 4.56 & 3.04 & 1.48 \\
\hline 55 & Y. K. & 39 & q & 1,052 & 9.4 & 3.9 & 1.6 & 2.5 & 7.0 & 4.08 & 3.82 & 1.06 \\
\hline 56 & T. M. & 67 & 3 & 1,054 & 8.2 & 3.6 & 1.6 & 3.0 & 7.0 & 4.40 & 2.60 & 1.69 \\
\hline 57 & T. Y. & 23 & q & 1,052 & 9.8 & 5.1 & 1.6 & 2.0 & 7.7 & 4.72 & 2.98 & 1.58 \\
\hline 58 & T. N. & 50 & ㅇ & 1,057 & 9.4 & 3.2 & 1.6 & 3.5 & 7.5 & 4.48 & 3.02 & 1.48 \\
\hline 59 & A. M. & 29 & $\delta$ & 1,057 & 9.3 & 4.0 & 1.9 & 3.8 & 8.0 & 5.04 & 2.96 & 1.70 \\
\hline 60 & H. M. & 22 & $\hat{o}$ & 1,057 & 9.1 & 3.8 & 2.2 & 3.8 & 8.3 & 4.96 & 3.34 & 1.48 \\
\hline 61 & $\mathrm{~T} . \mathrm{K}$. & 22 & $\hat{\delta}$ & 1,057 & 9.8 & 3.2 & 1.5 & 2.9 & 7.1 & 4.72 & 2.38 & 1.56 \\
\hline 62 & T. Y. & 15 & $\delta$ & 1,050 & 9.6 & 3.1 & 2.2 & 5.0 & 7.3 & 4.72 & 2.58 & 1.83 \\
\hline 63 & T. T. & 44 & q & 1,052 & 9.4 & 3.4 & 1.6 & 3.6 & 7.0 & 5.28 & 1.72 & 3.07 \\
\hline 64 & K. T. & 41 & ㅇ & 1,054 & 10.3 & 3.3 & 1.5 & 3.5 & 7.6 & 5.36 & 2.24 & 2.48 \\
\hline 65 & O. T. & 14 & $\hat{\delta}$ & 1,053 & 10.1 & 3.3 & 1.7 & 5.7 & 7.2 & 4.80 & 2.40 & 2.00 \\
\hline 66 & T. $O$ & 27 & $\hat{\delta}$ & 1,059 & 9.6 & 3.3 & 1.7 & 3.4 & 7.2 & 5.44 & 1.76 & 3.09 \\
\hline 67 & $\mathrm{~K} . \mathrm{K}$. & 33 & $\hat{o}$ & 1,057 & 9.8 & 4.0 & 1.8 & 3.8 & 8.0 & 5.36 & 2.64 & 2.03 \\
\hline 68 & H. T. & 58 & ㅇ & 1,054 & 9.8 & 4.0 & 1.4 & 3.2 & 7.4 & 4.72 & 2.68 & 1.76 \\
\hline 69 & I. F. & 69 & $q$ & 1,052 & 9.8 & 4.4 & 1.3 & 3.9 & 7.4 & 5.20 & 2.20 & 2.36 \\
\hline 70 & N. M. & 34 & $\delta$ & 1,053 & 9.2 & 3.4 & 1.4 & 4.2 & 7.0 & 4.72 & 2.28 & 2.07 \\
\hline 71 & K. S. & 41 & q & 1,053 & 9.4 & 3.1 & 1.0 & 3.3 & 6.9 & 5.44 & 1.46 & 3.72 \\
\hline 72 & M. S. & 19 & ㅇ & 1,055 & 9.8 & 3.1 & 1.7 & 3.6 & 8.1 & 4.96 & 3.14 & 1.58 \\
\hline 73 & Y. S. & 42 & ㅇ & 1,053 & 9.6 & 4.2 & 1.5 & 3.1 & 6.9 & 4.72 & 2.18 & 2.16 \\
\hline 74 & M. K. & 39 & $\hat{o}$ & 1,055 & 10.0 & 4.2 & 1.5 & 2.8 & 6.8 & 5.36 & 1.44 & 3.72 \\
\hline 75 & K. M. & 20 & 우 & 1,053 & 10.0 & 4.0 & 1.4 & 3.3 & 7.9 & 5.20 & 2.70 & 1.92 \\
\hline
\end{tabular}




\begin{tabular}{|c|c|c|c|c|c|c|c|c|c|c|c|c|}
\hline 76 & $\mathrm{~K} \cdot \mathrm{H}$. & 50 & 우 & 1,049 & 9.2 & 4.0 & 1.9 & 4.2 & 7.3 & 4.88 & 2.42 & 2.01 \\
\hline 77 & $\mathrm{~K} \cdot \mathrm{K}$. & 63 & $\delta$ & 1,059 & 9.8 & 3.8 & 1.6 & 2.2 & 7.3 & 4.96 & 2.34 & 2.11 \\
\hline 78 & M. K. & 37 & ㅇ & 1,050 & 9.8 & 3.8 & 1.3 & 3.0 & 7.0 & 5.36 & 1.64 & 3.28 \\
\hline 79 & $\mathrm{~N} \cdot \mathrm{T}$. & 57 & $\hat{o}$ & 1,050 & 9.6 & 3.8 & 2.0 & 2.5 & 7.7 & 5.28 & 2.42 & 2.18 \\
\hline 80 & $\mathrm{~K} \cdot \mathrm{N}$. & 55 & 우 & 1,052 & 10.0 & 5.0 & 1.4 & 4.6 & 7.5 & 5.04 & 2.46 & 2.05 \\
\hline 81 & S. T. & 22 & ㅇ & 1,050 & 9.0 & 3.2 & 1.7 & 2.5 & 7.1 & 4.72 & 2.38 & 1.98 \\
\hline 82 & S. F. & 27 & $\hat{\delta}$ & 1,056 & 9.2 & 4.2 & 1.7 & 4.6 & 7.4 & 4.96 & 2.44 & 2.03 \\
\hline 83 & A. M. & 17 & 우 & 1,051 & 9.8 & 3.3 & 1.3 & 3.4 & 7.0 & 4.24 & 2.76 & 1.53 \\
\hline 84 & S. M. & 39 & $\delta$ & 1,059 & 10.0 & 4.0 & 1.4 & 3.1 & 7.6 & 5.36 & 2.24 & 2.38 \\
\hline 85 & $\mathrm{Y} \cdot \mathrm{K}$ & 16 & 우 & 1,050 & 10.0 & 4.8 & 1.0 & 3.5 & 7.0 & 5.44 & 1.56 & 3.48 \\
\hline 86 & S. T. & 22 & $\varepsilon$ & 1,050 & 9.6 & 3.6 & 1.5 & 3.8 & 7.3 & 5.36 & 1.94 & 2.76 \\
\hline 87 & S. F. & 55 & 우 & 1,052 & 10.0 & 4.8 & 1.5 & 3.6 & 7.4 & 4.72 & 2.68 & 1.88 \\
\hline 88 & M. T. & 48 & ㅇ & 1,052 & 9.4 & 4.4 & 1.7 & 4.3 & 7.2 & 4.72 & 2.43 & 1.90 \\
\hline 89 & T. M. & 14 & $\hat{\delta}$ & 1,053 & 9.4 & 4.4 & 1.5 & 4.8 & - & - & - & - \\
\hline 90 & $\mathrm{Y} . \mathrm{K}$. & 23 & $\hat{\delta}$ & 1,059 & 10.1 & 4.1 & 1.4 & 3.1 & 7.6 & 5.04 & 2.56 & 1.96 \\
\hline 91 & $\mathrm{~K} \cdot \mathrm{K}$ & 52 & 우 & 1,052 & 10.0 & 4.0 & 1.2 & 4.2 & 7.1 & 4.64 & 2.46 & 1.88 \\
\hline 92 & $\mathrm{Y} . \mathrm{K}$ & 20 & 우 & 1,051 & 9.8 & 3.2 & 1.7 & 3.9 & 7.4 & 4.96 & 2.44 & 2.03 \\
\hline 93 & Y. S. & 19 & $\hat{o}$ & 1,056 & 9.6 & 3.4 & 2.1 & 4.0 & 7.1 & 5.44 & 1.66 & 3.27 \\
\hline 94 & M. T. & 43 & $\hat{\delta}$ & 1,052 & 8.7 & 3.2 & 1.5 & 4.5 & 7.5 & 4.56 & 2.94 & 1.55 \\
\hline 95 & S. Y. & 18 & $\delta$ & 1,057 & 9.8 & 2.0 & 1.5 & 3.6 & 7.6 & 5.28 & 2.32 & 2.27 \\
\hline 96 & $\mathrm{~K} . \mathrm{K}$. & 36 & $\hat{\delta}$ & 1,057 & 9.0 & 2.8 & 1.8 & 2.2 & 7.0 & 5.36 & 1.64 & 3.26 \\
\hline 97 & T. N. & 36 & $\hat{o}$ & 1,054 & 9.8 & 4.3 & 1.5 & 3.6 & 7.2 & 4.72 & 2.48 & 1.97 \\
\hline
\end{tabular}

第 4 表八丈島住民と杉前区住民との血清分析比較表

\begin{tabular}{|c|c|c|c|c|c|c|c|c|c|c|}
\hline & \multirow{2}{*}{$\begin{array}{l}\text { 人 } \\
\text { 数 }\end{array}$} & \multirow{2}{*}{$\begin{array}{l}\text { 血 液 } \\
\text { 比 重 }\end{array}$} & \multicolumn{5}{|c|}{ 血 } & \multicolumn{3}{|l|}{ 清 } \\
\hline & & & $\begin{array}{l}\text { 総 } \mathrm{Ca} \\
\mathrm{mg} / \mathrm{dl}\end{array}$ & $\begin{array}{c}\text { 透析性 } \\
\mathrm{Ca} \\
\mathrm{mg} / \mathrm{dl}\end{array}$ & $\begin{array}{l}\text { 総 } \mathrm{Mg} \\
\mathrm{mg} / \mathrm{dl}\end{array}$ & $\begin{array}{l}\text { 無機燐 } \\
\mathrm{mg} / \mathrm{dl}\end{array}$ & $\begin{array}{l}\text { 総蛋白 } \\
\text { g/dl }\end{array}$ & $\mid \begin{array}{ll}\text { アルブミ } \\
\begin{array}{c}\text { g/dl } \\
\text { (A) }\end{array}\end{array}$ & $\left|\begin{array}{ccc}ク ゙ & \text { ブ } \\
\text { y } & (\mathrm{G}) \\
\mathrm{g} / \mathrm{dl}\end{array}\right|$ & $\mathrm{A} / \mathrm{G}$ \\
\hline 杉並調查第 1 回 & 89 & 1,053 & 9.7 & 3.9 & 1.6 & 3.4 & 7.4 & 4.6 & 2.8 & 1.7 \\
\hline 杉並調査 第 2 回 & 40 & 1,052 & 9.8 & 3.7 & 1.2 & 3.6 & 7.5 & 4.7 & 2.8 & 1.7 \\
\hline 八 & 76 & 1,054 & 9.3 & 2.9 & 1.1 & 3.6 & 7.2 & 4.2 & 3.0 & 1.4 \\
\hline
\end{tabular}

第 5 表七島䏶罹患した人の血清分析結果

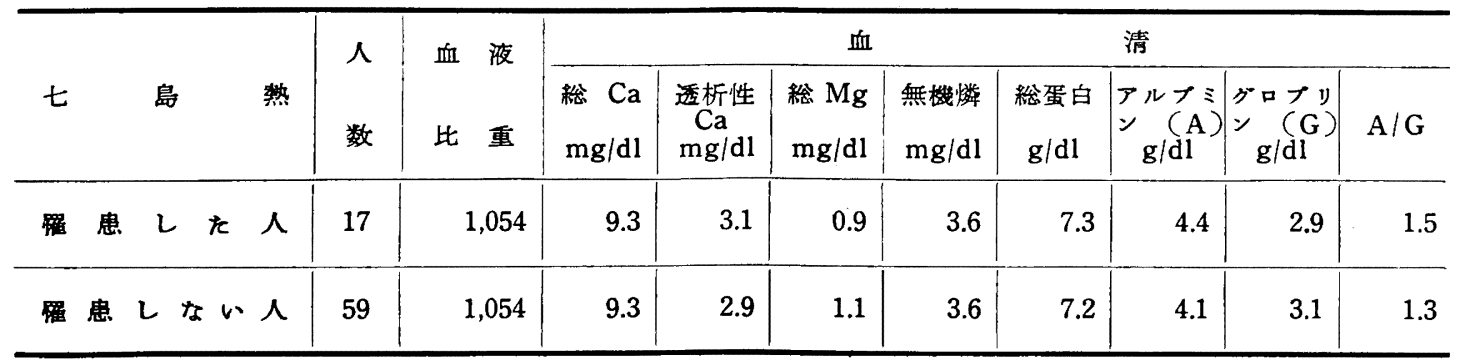


性 Ca の低值が考えられる。又八丈島民の米牙異常の多 いことも $\mathrm{Ca}$ 低值と関係があると思われる。無機 $\mathrm{P} は$ は ぼ同值であるが，一般に無機 $\mathrm{P}$ は透析性と逆相関である のが普通で，八丈島民の如く透析性 Ca が著しく低值で あれば，当然無機 Pは異常に増加すべきであるのに，燐 椇取の不足と共に粼酸醭素に賦活する $\mathrm{Mg}$ 量の低值のた めであろ5と思われる。血清中総蛋白の低值は, 蛋白食 品の掑取量が杉並の $80 \%$ 低值であり，掑取不足からの， 栄養の不均衡の結果である。又グロブリンの増加, 言い かえれば $\mathrm{A} / \mathrm{G}$ 低值は第 2 報で報告した最低血圧の低值 とる関倸があるのではないかと思われるか，次の機会に 更に検討したいと考える。

この調查中七島熱に䍜患した人が17名いた。この分析 結果と䍦患しない人の分析結果を比較してみると，第 5 表に示寸如く, 血液比重, 血清中の総 $\mathrm{Ca}$, 透析性 $\mathrm{Ca}$,

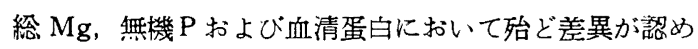
られなかつた。

$$
\text { 約論 }
$$

八大島民76名の血液成分の分析を行い，先に策施した
杉並地区の栄恶調と比較検討を行つた結果，八丈島民に 血清成分中特に総 $\mathrm{Ca}$ ・透析性 $\mathrm{Ca}$ の著明な低值を報告1 た。

（要旨は昭和32年11月16日女子栄全短期大学におい 開催された栄盖食樶学会関東絵会において発表した。 文献

1）吉川春寿：硫酸銅法 (医学書院) (昭22)

2）柳沢交正：カルシウム及びマグネシウム新定量 法子代謝 (文光堂) (1955)

3) Yanagisawa, F. : J. Biochem., 42, 3 (1955)

4）楖沢交正：日本医事新報，1676，32 (1955)

5) Fiske, C.H. and Subba Row, Y. : J. Biol. Chem., 66, 375 (1925)

6) Harold J. Fister : Manual of Slandardizrd Procedures for Spectrophotometric Chem ictry. (1950)

7) Gornall, A. G. Bardawill, C. J. and David, M. M. : J. Biol. Chem., 177, 751 (1949) (東京都衛生局栄揫課・東京都立衛生研究所)

\section{カルシウムへの順応}

犬を 2 匹ずつ 3 群に分けカルシウム (Ca) の異る量 を与え, 平衡試験を行つたところ, 低 $\mathrm{Ca}$ 食では高 $\mathrm{Ca}$ の啺台より有効 $\mathrm{Ca}$ か保留された。又平衡を保つに必要 な $\mathrm{Ca}$ 量はそれ以前の $\mathrm{Ca}$ の摄取量に影響された。低 $\mathrm{Ca}$ 食に順応した犬では小量の $\mathrm{Ca}$ で平衡に達し， $0.03^{4}$ \% Ca 食でも常に負とはならなかつた。骨の化学的及び
組織学的の検査も異常を見出し得なかつた。

Adaptation to different calcium intake in dog. S. N. Gershoff., M. A. Lagg. and D. M. Hegsted J. Nutr. $64: 303,1958$

（野 崎） 